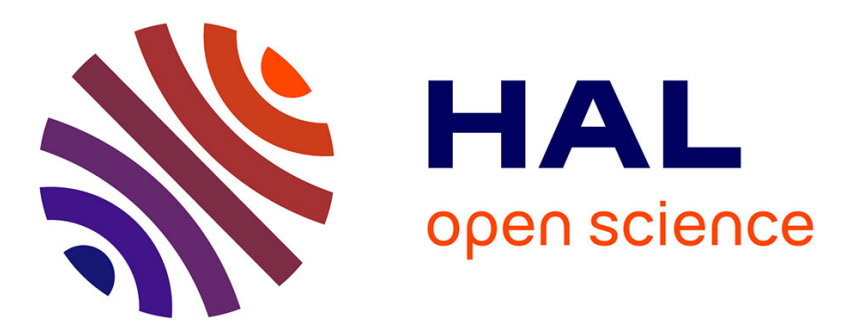

\title{
Citizen engagement processes as information systems: the role of knowledge and the concept of translation quality
}

Tom Horlick-Jones, Gene Rowe, John Walls

\section{- To cite this version:}

Tom Horlick-Jones, Gene Rowe, John Walls. Citizen engagement processes as information systems: the role of knowledge and the concept of translation quality. Public Understanding of Science, 2007, 16 (3), pp.259-278. 10.1177/0963662506074792 . hal-00571119

HAL Id: hal-00571119

https://hal.science/hal-00571119

Submitted on 1 Mar 2011

HAL is a multi-disciplinary open access archive for the deposit and dissemination of scientific research documents, whether they are published or not. The documents may come from teaching and research institutions in France or abroad, or from public or private research centers.
L'archive ouverte pluridisciplinaire HAL, est destinée au dépôt et à la diffusion de documents scientifiques de niveau recherche, publiés ou non, émanant des établissements d'enseignement et de recherche français ou étrangers, des laboratoires publics ou privés. 


\title{
Citizen engagement processes as information systems: the role of knowledge and the concept of translation quality
}

\author{
Tom Horlick-Jones, Gene Rowe and John Walls
}

An important direction in recent thinking about public understanding of science and technology is embodied in the international trend within many democratic countries towards the promotion of citizen engagement. These developments entail the participation and deliberative involvement by lay publics in planning, decision-making and policy-making situations. In this paper we argue that citizen engagement exercises can usefully be understood as information systems. This characterization leads us to propose that the effectiveness by which such exercises utilize sources of knowledge-what we term their translation quality - should be adopted as a new criterion for their evaluation. We illustrate the applicability of this proposal by analyzing the $G M$ Nation? public debate, a government-sponsored citizen engagement exercise that took place in Britain in 2002-3.

\section{Introduction}

The notion of citizen engagement has become a central feature in public policy discourse within many democratic countries, where it is regarded as a means of addressing a number of perceived sources of potential crisis in contemporary governance; namely deficits of knowledge, trust, and legitimacy (Dryzek, 2000; CEC, 2001; OECD, 2001). As a result, various forms of participative and deliberative involvement by lay citizens are starting to play an increasingly important role in shaping policy, in particular in areas concerning science and technology. These changes bring new opportunities and challenges for public understanding of science.

In the context of these developments an unprecedented experiment in government-sponsored citizen engagement took place in Britain in 2002-3. This was concerned with the possible commercial cultivation of genetically modified (GM) crops in the UK. In this paper we draw upon our experience of evaluating this government-sponsored initiative, which was branded GM Nation? The Public Debate (Public Debate Steering Board, 2003a). Elsewhere, we have reported in detail on various aspects of the debate and the evaluation that we conducted (Horlick-Jones et al., 2002, 2003, 2004, 2006, 2007, in press; Pidgeon et al., 2005; Rowe et al., 2005, 2006, in press). Here, we focus on one particular aspect of the functioning of the debate process: the effectiveness of that capacity by which it utilized sources of knowledge, 
including the ways in which conclusions drawn from one stage of the process became a source for its subsequent stages, informing and shaping them. We will term this characteristic of the debate process its translation quality.

Before proceeding, we first recognize that it is important to draw a distinction between our use of the term translation and the use that has already been made by other researchers in the context of engagement processes (National Research Council, 1996). As we understand it, their use of the term (p. 14) refers to a conception of a hypothetical instrumental process that might provide scientific knowledge in a user-friendly form suitable for use by decisionmakers. They are critical of this notion, and stress the need for multiple forms of knowledge, including lay perspectives, to be used in decision-making in an integrated way, as part of an analytic-deliberative process. Our concept of translation seeks to capture how effectively various sources of knowledge are utilized in just such an interactive and integrative process.

In the following sections, we first consider the roles of different forms of knowledge and information in engagement processes, and we develop a conception of such processes as information systems. We then introduce the notion of translation quality as the basis for systematically evaluating this dimension of engagement processes. In subsequent parts of the paper we illustrate the relevance of these ideas by examining their applicability to the various component parts of the GM Nation? debate. Finally, we consider the case for translation quality to be adopted as an evaluation criterion for future engagement exercises.

\section{Knowledge, information and the notion of translation quality}

Citizen engagement exercises are centrally concerned with lay understandings of, and views about, certain issues in question, with a view to incorporating them in a process of decisionmaking. There is an implicit assumption here that lay perspectives form a legitimate, and workable, basis for conducting a process of this nature; one with perhaps far-reaching policy implications. This idea might still be regarded as radical, or even dangerous, in some quarters. After all, some would suggest that lay publics often display "irrational" views towards risk issues; views that are certainly not scientific, and perhaps inappropriate to inform the making of important decisions.

Importantly, much work in the public understanding of science literature (e.g. Wynne, 1995; Irwin and Wynne, 1996; see also Horlick-Jones, 2005) has recognized that lay publics typically include a wider range of considerations than technical experts do in their reasoning processes; including matters that are of relevance to their everyday life. In this way the rationality associated with technical expertise may be seen as narrowly defined, and indeed alienating in terms of its apparent disregard for issues about which people may have strong value-commitments. We also note that recent years have seen the relative status of lay and expert knowledge becoming a matter of scholarly controversy, featuring an extended debate about the nature of what kind of "expertise" is conferred by what has been described as "the privilege of experience" (Williams and Popay, 1994; see also Collins and Evans, 2002). Advocates at one end of a spectrum of views identify such "lay epidemiology" as a substantive form of expertise, offering a challenge to conventional science-based professional expertise. Those at the other end of the spectrum are highly critical of this position, and see the term "lay expertise" as no more than an oxymoron (discussed in e.g. Prior, 2003).

Without pursuing this debate in detail, it is possible to observe that in practice lay knowledge can make possible an enhanced utilization of expert knowledge to address specific problem situations. Such knowledge offers the possibility of contextualizing, or re-framing, abstract, general knowledge, in order to engage more effectively with the specifics of, for 
example, everyday working practices, or the details of a patient's lifestyle (Petts, 1997; Horlick-Jones, 1998; Linell, 1998). Over thirty-five years ago the historian and philosopher of science Thomas Kuhn (1970) argued that differences between competing scientific theories could not be resolved simply by appeal to "the facts" if these theories were differently framed. These insights have led to more recent work on apparently intractable policy controversies, in which it is recognized that technical knowledge alone rarely resolves such conflicts when competing perspectives are based upon different ways of "looking" at the problem issue (Schön and Rein, 1994).

Combining these perspectives-contextualizing expert knowledge, and incorporating multiple framings-suggests that decision-making about such policy matters necessitates processes that are not wholly technical, nor social or political; but rather something that combines these approaches (Funtowicz and Ravetz, 1992; Horlick-Jones and Sime, 2004; Rosenhead and Mingers, 2001; Stirling and Meyer, 1999). Seen in this light, citizen engagement about technological issues emerges as an attempt to incorporate and reconcile competing perspectives subject to the constraints and opportunities afforded by the character of the issue in question. ${ }^{1}$

Capturing, and making effective use of, a range of different forms of knowledge emerges as a matter of central importance to the effectiveness of citizen engagement initiatives. We note that much of the recent literature on these exercises (e.g. Abelson et al., 2003) stresses the need for two-way communication between debate sponsors and the public, as well as deliberation between participants. Petts (1997) draws attention to the importance of such interactions in highlighting information needs, and prompting the examination of a plurality of expert sources. However, despite this awareness of the importance of information, knowledge and communication to the effective functioning of engagement exercises, we are not aware of any work that has considered closely the overall management of information and knowledge during such exercises. Existing evaluation criteria for engagement processes (see Rowe and Frewer, 2000, 2004) focus on their effectiveness as organizational processes. It is clear that there is also a need to consider such processes as information systems (cf. Checkland and Scholes, 1990).

Importantly, it is also clear that knowledge cannot be viewed as a "package" that can be transferred between stages of an engagement exercise in an unproblematic way. Rather, each stage entails situated processes of gathering, presenting, disputing and agreeing, framing and re-framing, and finally using different forms and sources of knowledge: activities that here we generically term translation. Given this complexity, how is it possible to evaluate the translation quality of engagement processes?

Some progress towards answering this question may be made by considering part of the literature on knowledge in organizational settings. Feldman's (1989) investigation of the role of information in policy-making stresses the key roles of framing, and the resulting selection or omission of matters of relevance. She also emphasizes the important role played by documents in encapsulating such processes of categorization. This latter focus is addressed in detail in Harper's (1998) ethnography of a large international organization. His notion of an "information career" - as information is gathered, analyzed, documented, transformed in various ways, and used by management structures to achieve certain ends-is particularly apposite in the current discussion. The key distinction between information and knowledge is taken up by a number of writers (e.g. Alvesson, 2004), who conclude that the latter entails an exercise in judgment based on experience or theory. A recent intervention by Jensen (2005) is particularly helpful in drawing out the significance of this distinction: recognizing that only information can be shared between members of an organization, and that the acquisition of knowledge entails processes of learning, re-framing and understanding.

The practical implementation of engagement exercises will additionally entail the transmission of information across organizational boundaries, and between lay understandings 
and professional interpretations. Here we note that Manning's (1988) analysis of emergency calls to the police provides some important insights into the character of such processes of sense-making and categorization, and transformations of "this" to "that." Importantly, his study serves to highlight the pivotal role of routine competencies and expectations on the part of the professionals in question. Typically the organizational infrastructure that implements and supports an engagement exercise will comprise an ad hoc consortium of executive agencies, each with their own operational norms, which come together simply for the duration of the exercise. These agencies may possess varying degrees of the competencies needed to implement the debate. Such considerations suggest that knowledge-handling by a given engagement exercise may well be a complicated, and potentially messy, process. These are important matters for the evaluation of the exercise's translation quality.

\section{The GM Nation? debate}

As noted above, we have already reported in detail elsewhere on the nature of this debate, and on the character of the evaluation we conducted. Here we briefly set out the structure of the debate, in order to identify its component parts and their interrelationships. The debate (see Figure 1) comprised a number of distinct stages:

- A process of desk research.

- A preliminary series of workshops, designed to allow a range of lay perspectives to frame the terms of the process.

- The production of stimulus materials to support the debate process.

- An open engagement phase, comprising public meetings, availability of information materials, a website, and the opportunity to comment on the issues or complete a questionnaire.

- A series of focus groups that were conceived as providing some degree of "control" over possible bias arising from the public engagement perhaps only attracting participation by those with pre-existing (and fixed) views.

It is possible to identify a number of information-related processes that would appear to have an important bearing on the overall effectiveness of the debate process. These information flows are illustrated schematically in Figure 2.

Specifically, there is a need to consider the quality of a number of activities that formed part of the debate process, including:

- The elicitation of lay perspectives, and how these were used to "frame" the debate.

- How stimulus materials designed to inform the debate were developed.

- How the public meetings and other publicly accessible conduits were used to gather information by the organizers.

- How the "Narrow-but-Deep" process functioned as a "control" mechanism.

- How the debate's Steering Board analyzed all the information at its disposal, and how it drew up overall findings.

\section{Framing the debate}

From an early stage, the organizers expressed a commitment that the public should be allowed to determine how the issues around GM were to be discussed during the debate. Here we 
November 2002

\begin{tabular}{l}
\hline Open Meetings \\
Tier 1 \\
Major 'national' \\
organised by S \\
Board executive \\
Tier 2 \\
Meetings organ \\
local councils o \\
organisations a \\
supported by S \\
Board executive \\
estimated) \\
Tier 3 \\
Local meetings \\
by community 9 \\
educational centron \\
( $\mathrm{n}=629$ estima \\
\hline \\
\\
Transcripts and \\
Rapporteurs' \\
Reports
\end{tabular}

\section{Foundation Discussion Workshops}

Total of 9 large 'focus groups'. 8 with ordinary citizens pre-selected to represent a spread of socio-demographic characteristics. 1 further meeting held with GM stakeholders.

Exploratory 'framing' of issues in preparation for the main debate process the following summer.

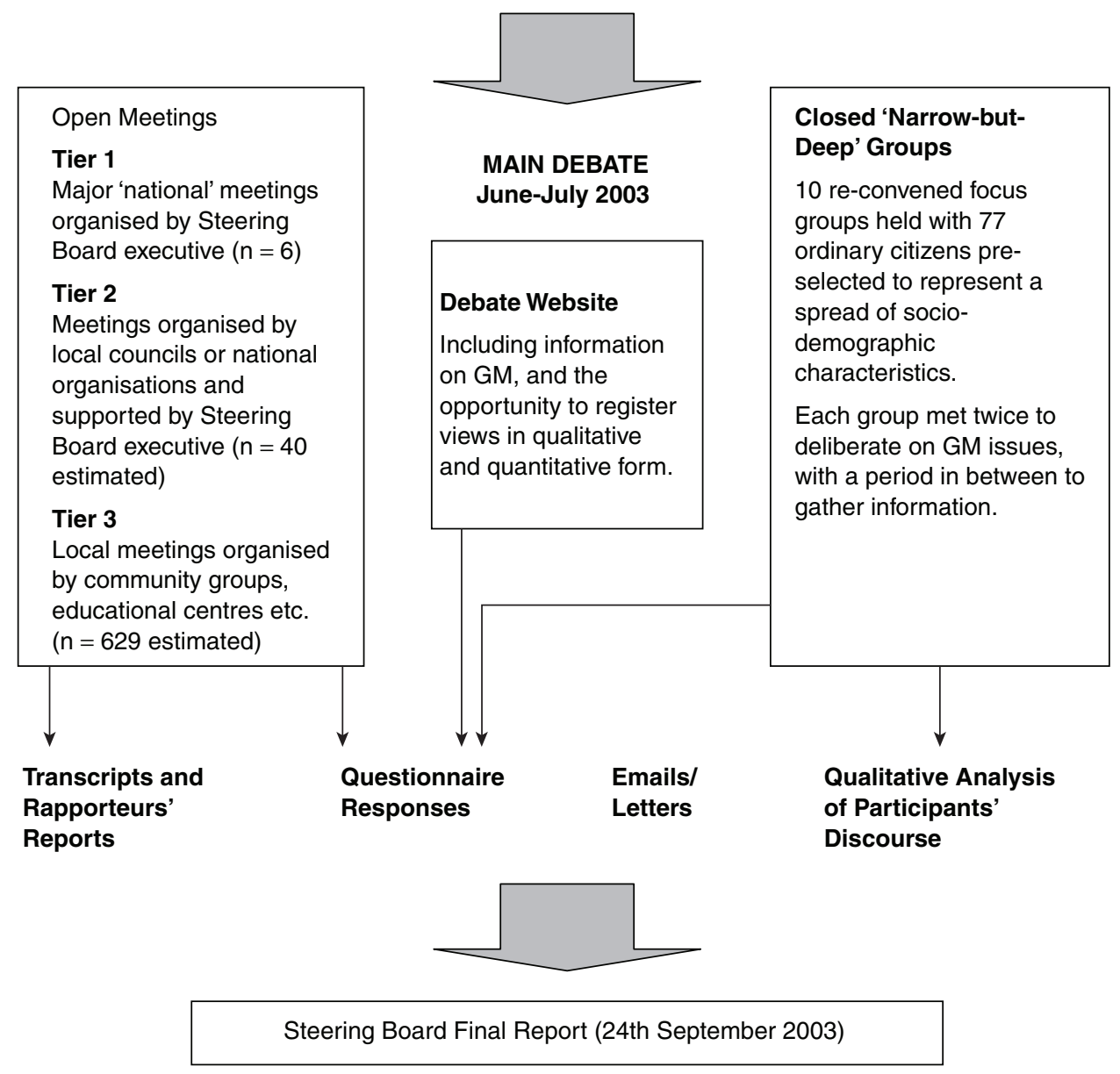

Figure 1. The GM Nation? debate process (after Pidgeon et al. (2005); reproduced with permission).

consider how this task was addressed. In order to elicit lay framings of GM-related issues, a series of discussion groups (known as Foundation Discussion workshops) were organized, with the objective of investigating how a cross-section of the lay public tries to make sense of these issues.

Nine discussion groups were convened. Eight of the groups comprised individuals who were not already engaged with the issues, and a single workshop was composed of those who were actively involved and interested in GM issues. In methodological terms, the workshops 


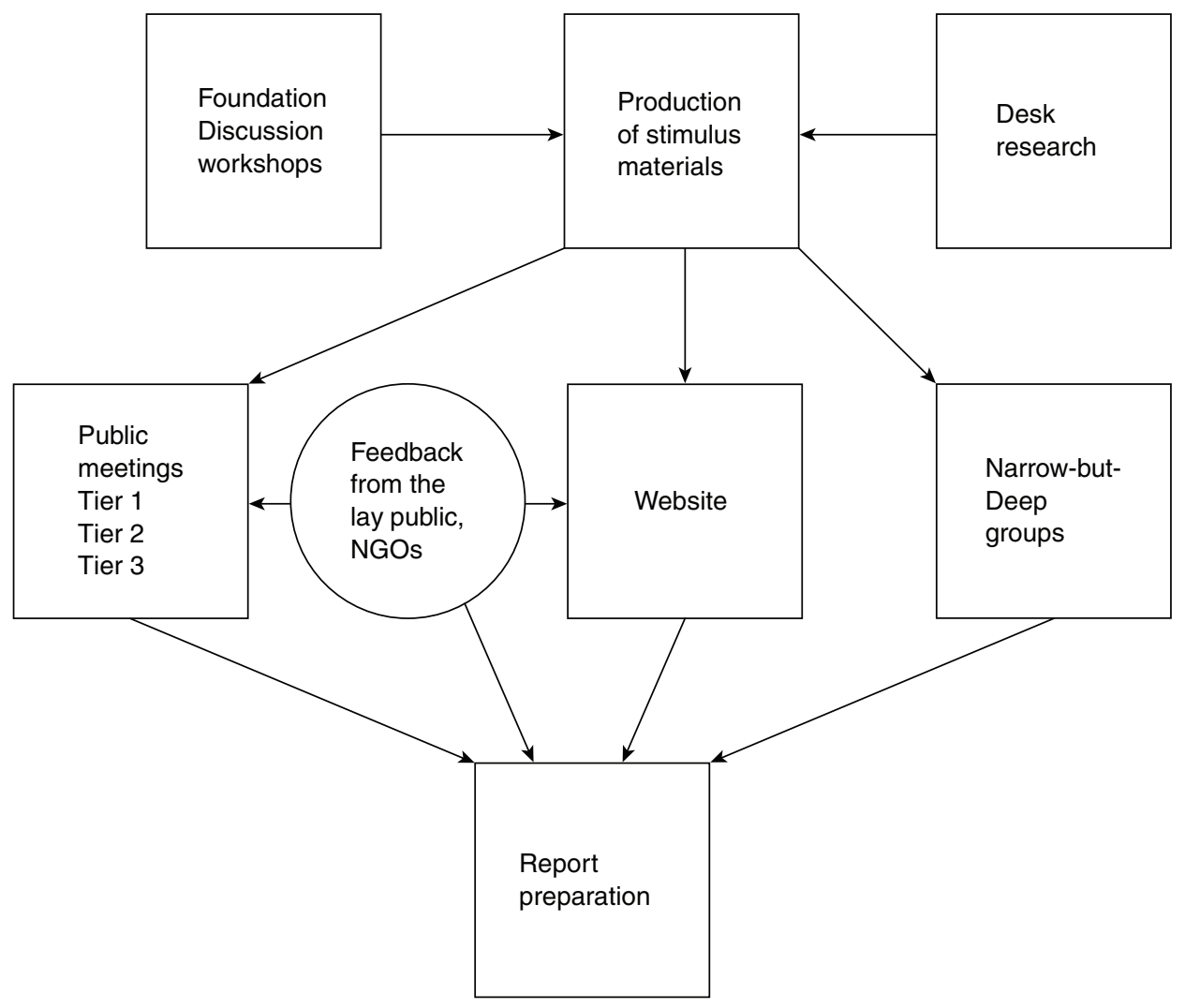

Figure 2. Flows of information between stages of the debate.

were rather like large focus groups. They utilized a range of moderation techniques, some of them more unusual than others, but including some elements that were indeed novel. These included the use of a number of games that made possible the representation of contrasting participant views in graphic and amusing terms, storytelling, and the presence of a professional cartoonist to provide stimulus material.

The groups were much larger than those typically utilized in focus group-based research. Participant interactions within the group meetings were highly mediated by the (two) facilitators. Unsurprisingly, therefore, the groups did not generate much in the way of quasi-naturalistic talk: an invaluable source for tapping everyday sense-making practices (Horlick-Jones, 2005; Petts et al., 2001). However, the facilitators demonstrably sought to avoid imposing exterior frames on the group discussions, and to promote the identification of shared everyday categories. These are techniques often adopted by social researchers using focus groups (Bloor et al., 2001), and our observations suggest that the facilitation practice was highly professional in this respect.

The group facilitators made audio recordings of the entire proceedings. The quality of these recordings was quite poor in places, and we recognize that this could have resulted in potentially important data being lost, although we have no specific evidence to suggest that was the case. The facilitators also retained a variety of flipcharts used during the various "games" and procedures. Finally, they also retained the work of the cartoonist who was present at each workshop, and whose work was, it seems, at least in part inspired by the unfolding discussions. 
The facilitators' report on the group-based exercise (Corr Wilbourn, 2003a) does not indicate how all these data were analyzed. They describe their methodology as following "the principles of phenomenological and process-oriented qualitative research" (p. 6) with the "specific application" of this approach being developed in-house. Our informal interviews with the facilitators indicated that their analytic approach was rather similar to standard textbook methods for qualitative research.

This analysis of the group sessions identified six frames that the participants used when discussing, and trying to make sense of, GM issues. These were (Corr Wilbourn, 2003a):

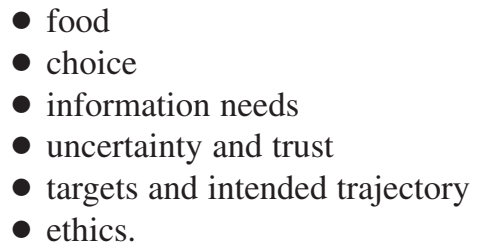

These findings also identified numerous factual areas where participants expressed a wish to know more.

The structure of lay framing of GM-related issues revealed by these workshops was in close agreement with the findings in the recent risk perception literature, for example over the way in which people use shared categories drawn from their everyday lives-like food, health and trust in decision-makers - in collectively accomplishing an understanding of GM issues (Grove-White et al., 1997; Marris et al., 2001; Petts et al., 2001). They also identified a high degree of ambivalence in attitudes towards GM, something which figured strongly in the findings of our survey work, where we found that more than half of the lay public were not sure whether GM food should be promoted or opposed (discussed in Horlick-Jones et al., 2007).

Overall, we concluded that the workshop methodology was sound, as an exercise in information elicitation and gathering, and, in this respect, it was able to capture most of the data required by the organizers. However, whilst the workshops were highly effective with regard to eliciting framing information, they were less successful in their secondary task of ascertaining what would encourage members of the public to engage actively with the wider debate process. The single workshop comprising people already engaged in GM-related issues agreed that the debate should disseminate "the facts" about GM, but, unsurprisingly, disagreed over which facts.

\section{The "facts" about GM: informing the debate}

The debate organizers decided to develop a range of stimulus materials to ensure participants in the debate were informed about the nature of the arguments about GM. It was envisaged that these materials would also set out a range of technical evidence regarded by most protagonists as being of relevance. The preparation of these materials proved problematic, not least because of the need to strike a balance between the relative status of quite well-established scientific findings (albeit subject to uncertainty and so potentially fallible) and wider value-based issues, like political and ethical considerations. We note that the US National Research Council (1996) report on deliberative processes mentioned above recognized that there is no easy way to strike this balance.

As a first stage, background research was commissioned: a review of the literature about public attitudes in the UK to GM issues, focusing on GM crop commercialization; and a 
review of the experience in the UK and elsewhere, of implementing deliberative techniques in public engagement exercises. This work was carried out partly by the main debate contractor and executive (COI Communications), and partly by a subcontractor. This material could fairly be described as sound but unexceptional. It contained the sort of information that one might not unreasonably expect those who were appointed to implement a major exercise like the GM debate to already possess.

The preparation of the stimulus materials entailed the assembly of an appropriate body of knowledge. It was argued that given the nature of technical terms and ideas used in debates about GM, many of which may be unfamiliar to the lay public, there was a need to create an "agreed core" of information. The subcontractors appointed to carry out this work were advised that whilst the brief was concerned with creating "objective" information, there was a case to include "opposing views" because "this is often how people encounter information in real life" (quotes taken from the contractors' brief, December 2002).

In practice, the subcontractors interviewed a number of engaged stakeholders, including the members of the debate Steering Board, drawing on a set of questions forming an output from the Foundation Discussion workshops. Here, it seems, was the first "translation link" with the earlier stage of the debate.

The nine interview areas initially comprised:
A. Basic information and definitions
B. Current status of GM
C. Rationale
D. Possible risk to health
E. Other possible effects
F. Regulation and monitoring of safety
G. Boundaries
H. Trust and confidence
I. Moral and ethical issues.

These areas and their constituent questions (up to eight for each category) were identified by the Foundation Discussion workshop subcontractors, and are contained in their report on the workshops (Corr Wilbourn, 2003a). Here, questions posed by participants during the various workshop exchanges had been grouped according to common themes.

As they stand, the questions address matters that are largely of a technical nature: "What is GM?"; "How is it done?"; "Who eats GM food?"; "Why do it?"; "What's in it for me?"; "How do I know that it will be safe?" Clearly competing voices in debates about GM would provide different answers, and indeed, the responses obtained by the subcontractors contained a diversity of perspectives on these "factual" matters. These were eventually organized in terms of a series of pithy for/against statements.

The stimulus materials took the form of a video, "workbook" and CD-ROM. The video used the device of using conversations between three small groups of people-members of the lay public, scientists and farmers - to articulate the different kinds of argument typically used in debates about GM. It is not clear to us how these individuals were selected, or the extent to which the conversations were scripted. The content of the workbook (a glossy 48 page pamphlet) and CD-ROM drew on the "core" information mentioned above, and contained a series of questions about GM, its regulation, possible impacts and so on. This material was presented in the form of a paragraph or two of "views for" and "views against." The sources of these arguments, present in the initial "information content" text, had been removed. The final form of the stimulus material went through a series of slippages from early 
plans; for example the CD-ROM was originally intended to take a much more interactive form, however this did not happen. The content of the workbook was made available on the debate website, which also provided access to a quite extensive range of documentation associated with the debate.

The activities associated with the production of the stimulus materials entailed a number of translation processes. First, a range of questions elicited by the Foundation Discussion workshops were used to shape the gathering of information that was used in those materials. Interestingly, these questions were used rather than attempting to adopt the framings identified in the workshop report. It could be argued that by substituting questions for frames, lay perspectives were being constructed in "deficit" terms; as an absence of expert knowledge. This observation raises a difficult technical question, namely: how might one capture such framings in a way that they can be used in practical ways to shape the debate process? Whilst one could argue that a set of questions in some way reflects the perspectives and preoccupations of a frame, or set of frames, this would appear a rather impoverished way of embodying the totality of shared understandings, sources of relevance, symbolic linkages and uses of language which are characteristic of socially organized "ways of seeing" (Goffman, 1975). Here we have identified an important challenge for the concept of translation quality.

Turning now to the use of information gathered in the production of the stimulus materials, we note that the finalized materials presented for/against arguments in a way that stripped the arguments from their source information and political context. As it stood, there was no way to distinguish statements based upon well-established scientific knowledge, from those that drew upon a variety of other sources. Arguably, important doubts exist about the extent to which information decontextualized in this way from its sources can play a meaningful role in informing a debate of this nature.

To illustrate this point, we briefly consider one of the questions contained in the GM Nation? stimulus materials (Public Debate Steering Board, 2003b). The text poses the question: "is GM food safe?" Two columns of text follow this heading, labeled "Views for" and "Views against." The first column contains the statement: "The regulatory bodies that exist are independent of industry and work in the public interest." The second column contains the statement: "Current tests assume that GM crops are fundamentally the same as non-GM crops, which is not the case." Neither statement (both of which, it should be noted, are contested by some stakeholders) is justified on the basis of any source or reference.

We found that the overwhelming view of participants in the debate's public events, and of various stakeholders and key actors that we interviewed, was that the quality of the stimulus material was bland and unsatisfactory (Horlick-Jones et al., 2007). Our analysis suggests that here the debate performed poorly with respect to translation quality.

\section{The public meetings}

The organizers produced a short questionnaire, or "feedback form" that was distributed to all participants in all component parts of the debate. It was also available on the website. This questionnaire contained thirteen items on the possible costs and benefits of GM crops, and drew, in a rather loose way, on the questions posed by the Foundation Discussion workshops. In addition, the organizers recruited observers for the six "national" Tier 1 meetings, whom we understand collected qualitative material describing the form and outputs of the discussions.

In the Tier 1 meetings, the plenary sessions were professionally introduced (drawing on some of the stimulus material) and facilitated. However, much of these meetings were organized around small round-table discussions between participants. We noted that participants 
engaged in these discussions made extremely limited use of the stimulus materials. The feedback from each table to a final plenary was delivered by an untrained volunteer, and limits on the time available resulted in a tendency for quite complex arguments to be reduced to simplistic formulations. The Tier 1 plenary sessions were audio taped and subsequently transcripts were made which were posted on the debate website. The organizers' observers, who were free to monitor the discussions around each table, were also volunteers who, as far as we are aware, worked in a way that was not coordinated or standardized across the various meetings. We conclude that the organizers were restricted in their capacity to capture the rich detail of the discussions that formed a central part of the Tier 1 meetings.

Turning now to the Tier 2 (regional) and Tier 3 (local) meetings, perhaps the first point to make is that these took on a diversity of forms. Some of the Tier 2 meetings, which were typically hosted by local government bodies, were supported by the debate organizers and professionally facilitated. The organization of Tier 3 meetings was determined locally by their organizers. We were only able to gather limited information on the large number of Tier 2 and Tier 3 meetings, however the ones we observed featured reasonably good facilitation and presentations by expert speakers, with opportunities for questions and discussion. We have no way of measuring the typicality of this format. We understand that occasionally informal reports on local meetings were sent to the debate organizers, however these did not arise from a process of independent observation, so their quality cannot be guaranteed. The debate executive sent stocks of feedback questionnaires to all local meeting organizers, but the process of their distribution was not monitored by independent observers.

We conclude that the organizers' feedback questionnaires provided the main conduit for information gathering on the public meetings. There was very little in the way of systematic attempts to collect information on the rich detail of discussion and deliberation which formed part of these meetings.

We found that the participants in the public aspects of the debate were not representative of the general public as a whole, in terms of either demographic or attitudinal characteristics. For example, the self-reported educational level of participants in the Tier 1 meetings was considerably higher than the UK average (some two-thirds of respondents claimed to have a degree, compared to one-fifth of the population, aged between 16 and 74, according to the 2001 census). Participants in the open activities, including the Steering Board's questionnaire, were considerably more negative about GM food and crops than respondents in our survey were (Horlick-Jones et al., 2007). We also observed that these events were often dominated by discussions characteristic of a knowledgeable and experienced engagement in the GM issue, suggesting a pre-existing engagement with GM-related issues.

The form of discourse typical of exchanges among participants in these meetings is illustrated in the following extract from one of our team's fieldwork notebooks:

I arrive at the second table, one participant is holding forth, telling "the facts". There is a lot of technical talk among the group. Pusztai is mentioned [the scientist who claimed to show that rats fed on GM food became ill as a result]. "what about the Newcastle study", "loads of tests are needed" ... one clearly-frustrated participant exclaims: "it's all a big con".

Despite this clear bias in representation, it is not our view that the open meetings were without merit. It is important to recognize that engaged people with clear views on GM issues had a legitimate contribution to make in the debate. Moreover the exploration of their views was important, in view of their prominence within the political dynamics of wider debates about GM. More important, from the point of view of this paper, is whether participants were suitably informed by the stimulus materials, and whether their views were appropriately collected by the organizers. Our analysis would generally suggest this was not the case. 


\section{The "Narrow-but-Deep" process}

The debate organizers were aware that findings from the debate drawn from a self-selected sample of the lay public could be criticized for their possible bias. In order to attend to this difficulty, an additional closed component of the debate took the form of a series of focus groups, conceived as a "control" on the findings arising from the open parts of the debate process. These ten groups were recruited to provide a representative cross-section of the public designed deliberately to exclude people with an active interest in the GM issue. These groups each met twice, with an interval of two weeks during which participants were invited to explore the issues concerning GM using official stimulus materials, and any other materials they could find, and to keep diaries of their findings, conversations, thoughts and so on. Here the title of the process, "Narrow but Deep" (NBD), refers to the limited scope of representation (only 77 members of the public took part), while "deep" refers to the anticipated extended level of engagement and deliberation in these groups, in comparison to that typically possible during the open meetings.

Specific objectives of the NBD process included the following requirements:

- To use the frames identified by the public to facilitate debate and deliberation which focuses on what the public sees as the relevant issues surrounding GM.

- To enable access to the evidence and other balanced and substantiated information the public may want and need to debate the issues.

- Through deliberation and access to evidence, allow people to come to a considered view on the issue of GM, the possible commercialization of GM crops in the UK, and the options for proceeding with this commercialization.

As we have seen, the Foundation Discussion workshops had identified a number of frames used by laypeople in making sense of the GM issues. These were grounded in everyday lived experience. Despite the stated objectives, we could find no evidence that the NBD meetings were purposefully structured according to these framings, save by virtue of the participants being exposed to the debate's stimulus materials, and to the cartoons produced during the Foundation Discussion workshops. Rather, the NBD meetings were allowed to evolve in a largely unstructured fashion. In this way, the facilitators might be said to have followed the brief by simply allowing the lay categorizations to re-emerge in a naturalistic way.

The facilitators audio recorded each of the NBD sessions. In common with the Foundation Discussion workshop recording, these recordings were of quite poor quality in places, and some gaps were present. The diaries kept by participants during the two weeks between group meetings were collected at the end of the second meeting. The facilitators' report (Corr Wilbourn, 2003b) carrying out an examination of media stories identified in a random sample of the diaries. The report does not record any other form of analysis carried out on the diaries, neither does it state whether transcripts were prepared from the recordings, or how, in practice, the datasets collected were analyzed. The evidence at our disposal suggests that textbook techniques for qualitative data analysis were used for this analysis.

Standard GM Nation? feedback questionnaires were issued to the participants for completion on the spot at the start of both the first and second meeting of each group. In other words, none of the organizers' questionnaires were issued to participants by the organizers following the experience of the second meeting of the group (they did, however, complete our questionnaire, which was issued with a pre-paid envelope for them to take away with them). We were interested to note that the facilitators (Corr Wilbourn, 2003b: 38) describe the 
second questionnaire as the "post-deliberation one," and go on to describe the activities undertaken by participants during the "diary" phase as "the deliberation process" (p. 45). Our observations suggest that the second meetings of the group were indeed more deliberative in nature that the first meetings, however this process took place after the questionnaire was completed. There seems to be some confusion here over the meaning of the word "deliberation," and we can only speculate on the implications for the data analysis.

In the facilitators' report on the NBD process (Corr Wilbourn, 2003b), strong claims are made about the robustness of its findings. The process is said to "genuinely represent 'grassroots' opinions" (p. 8), and whilst it is recognized that the sample is too small for associated feedback questionnaire data to provide robust statistical evidence, "it is more than adequate to provide robust qualitative data." Significantly, the facilitators claim that "the sample is, we believe, an accurate reflection of those whose voices have not yet been heard on the issues surrounding GM" (p. 18).

In response to these claims, we note that there exists no hard and fast rule about how many focus groups need to be conducted in order to make strong claims regarding the validity of the resulting findings. The NBD process is based upon a sample of ten groups, each of which met on two occasions, and we recognize that many projects have used fewer groups to establish results publishable in peer-reviewed journals. Sufficient volumes of data need to be gathered in order to achieve saturation of the categories that emerge from analysis. Ideally sampling would continue until clear saturation is achieved. In practice, of course, it is often not possible to follow this procedure as the constraints of project budgeting necessitate the numbers of groups to be used are specified in advance. Of central importance here is the recognition that despite sometimes using relatively small numbers of groups, focus groupbased research can make reasonable claims about the validity of its findings because it seeks to uncover shared norms and interpretative resources present within a wider population with certain shared experiences (Bloor et al., 2001; Petts et al., 2001).

During the two-week interval between first and second meetings of the NBD groups, the participants were asked to explore the GM issue, and at the end of the first meetings were encouraged to discuss how this objective might be achieved. During this two-week "diary" exercise, the participants were therefore exposed to potentially significantly different experiences, directly relating to the GM issue. The diaries they kept suggest that these influences include a diversity of knowledge claims about GM-related issues, including those posted at many websites, a large proportion of which were anti-GM in nature. ${ }^{2}$ Arguably such differences in experiences create the potential for discussions at the second meetings of the groups to move off in new, perhaps idiosyncratic directions, thus calling into question the "accurate reflection of unheard voices" claims of the NBD findings.

A further consideration concerns the logic of the position in which participants in the groups were placed as a result of knowing little about the issues, and then going on a "crash course" during which they were exposed to an uncontrolled range of sources of knowledge and opinion about GM-related matters. Any new technology has potential unintended adverse consequences, and it is clearly not possible to be completely sure that the introduction of GM will not bring with it health and environmental problems. The recent UK experience of bovine spongiform encephalopathy (BSE) and other food scares strongly reinforces this caution. The participants might quite reasonably then ask "what's in it for me?," and the answer is not at all clear. In contrast, for instance, in the case of mobile telephones, where people clearly see themselves as gaining significant benefits, scare stories about adverse health consequences appear to have had little impact on the widespread use of this technology (Walls et al., 2005). We observed NBD participants displaying considerable enthusiasm for fantasy products like "GM chocolate that doesn't put on weight" (see Figure 3), suggesting that caution about GM 
may similarly be swept aside if suitably attractive commodities became available (HorlickJones et al., in press).

A final crucial aspect of the context in which the NBD participants found themselves was being disengaged from the constraints of the decision on GM commercialization. Our understanding of the philosophy behind the NBD methodology (based upon a presentation by the facilitators that we observed) suggests that the process design sought to avoid constraining participants with the responsibility for a decision. This relaxing of constraints raises important questions about the extent to which the NBD process can truly be described as "deliberation," in the dictionary sense of promoting the consideration and discussion of arguments for and against a measure, so as to resolve that tension. Quite simply, the logic of asking people who are largely ignorant of the issues, and who have no particular axe to grind or constraint to satisfy, to make up their minds about GM appears to propel them in the direction of caution.

The shaping of the NBD group processes by largely uncontrolled sources of knowledge is an important consideration for translation quality. Another important factor is the apparent confusion in the interpretation of the qualitative and quantitative data collected. Overall, we conclude that the translation quality of this stage of the debate was rather weak.

\section{The official findings of the debate}

We now consider the drawing up by the organizers and their executive of the findings of the debate. Members of the Steering Group met on two occasions during August 2003 in order to consider and discuss drafts of the final report that had been prepared by a professional writer hired to undertake this task. We were provided with observer status at both meetings. It is important to note that this final process of the debate-the rendering of conclusions from a voluminous range of disparate data — was the ultimate test of what we have termed translation quality.

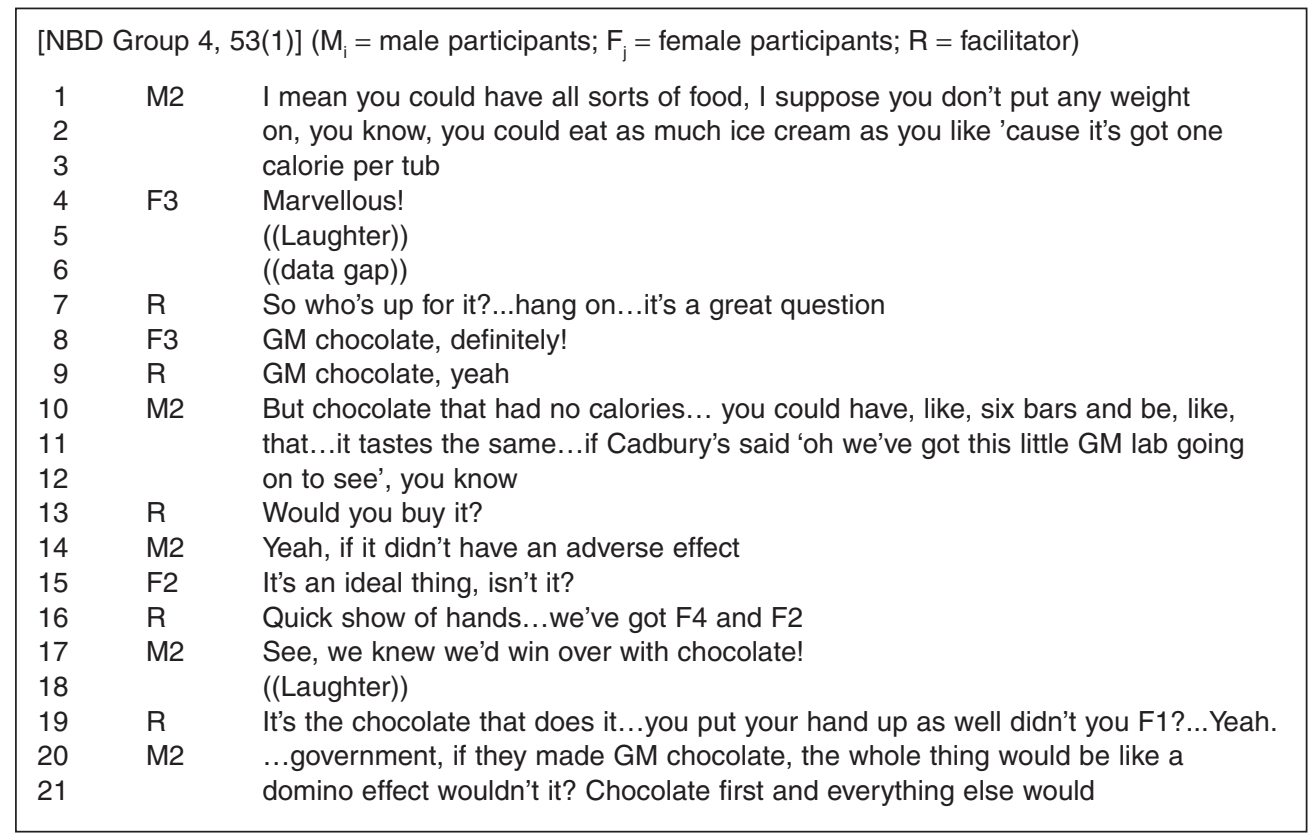

Figure 3. "GM chocolate": an example of talk during one of the "Narrow-but-Deep" group sessions. 
We first note the haste with which the report was put together in order to meet the agreed deadline, and the considerable pressure under which the writer worked. His contribution included not only drafting the report, but also significant work on analysis of a considerable volume of correspondence received by the debate secretariat. We recognize that the debate executive provided a certain amount of technical support, in particular in the analysis of the quantitative feedback data. However, given the volume of data collected, and the importance of the exercise, it seems extraordinary that the analytical process was not more adequately resourced. Given these constraints, it is a credit to the writer that the final report (Public Debate Steering Board, 2003a) is such a comprehensive and well-written document. However, significantly, it is not at all clear what processes of data analysis were used in analyzing the various sources of data collected by the debate, or how they were synthesized in order to arrive at the published findings.

As we have discussed in detail elsewhere (Horlick-Jones et al., 2007), we have some serious misgivings about these findings. We concur with the main conclusion, that significant levels of concern about certain aspects of GM exist among the British population, however we recognize the need to qualify this finding in the light of the high levels of ambivalence about the technology in question. We are also concerned about the suggestion that disengaged lay publics are not a "completely different audience with different values and attitudes from an unrepresentative activist minority" (Horlick-Jones et al., 2007: para. 195). Here the report seems to be arguing, on rather flimsy evidence, that if disengaged members of the lay public are exposed to "the facts" then their attitudes shift such that they have rather similar views to the (predominantly anti-GM) people who participated in the public meetings. Importantly, it is simply incorrect to claim that apart from minor differences the attitudes of the "post-experience" NBD groups were the same as those of participants in the public meetings (Campbell and Townsend, 2003; Pidgeon et al., 2005). As discussed above, the views of the NBD participants did indeed change as they learned more about the issues. However, there is a failure here to appreciate both the underlying dynamics of what appears to be a superficial similarity in views between these groups, and the extent of variation of attitudes across different populations within the lay public.

To conclude, we suggest that the translation quality of the final report production was flawed by an analysis that failed to be sufficiently sensitive to the nuances of interpretation of the various datasets. We recognize that this may have resulted from it being over-hurried and under-resourced, and appreciate the political pressures under which the organizers, their executive and consultants worked. This serious shortcoming underlines the importance of including translation quality as a generic consideration in the evaluation of engagement initiatives of this kind.

\section{Conclusions}

We have described how we concluded that what we term translation quality is an important consideration in the evaluation of engagement processes. We have also provided a detailed discussion of the relevance of this consideration by examining its applicability to the component parts of the GM Nation? public debate. It is clear that considerable work is needed to develop specific instruments and procedures in order to assess translation quality in ways more systematic than the simple narrative approach that we have adopted here. Nevertheless we suggest that the significance of this criterion for evaluation practice is evident.

Our analysis reveals that the GM Nation? debate was flawed in terms of this new criterion of translation quality. In essence, the gains from good initial work in identifying public framings 
Table 1. A summary of the various stages of the debate process from a translation perspective

\begin{tabular}{|c|c|c|c|c|}
\hline $\begin{array}{l}\text { Stage of } \\
\text { process }\end{array}$ & $\begin{array}{l}\text { Information/ } \\
\text { knowledge source }\end{array}$ & Actors/mechanisms & Outputs & Translation quality? \\
\hline $\begin{array}{l}\text { Foundation } \\
\text { Discussion } \\
\text { workshops }\end{array}$ & $\begin{array}{l}\text { Workshop } \\
\text { participants }\end{array}$ & $\begin{array}{l}\text { Subcontractor 1(facilitation } \\
\text { and analysis of audio } \\
\text { recordings of discussions } \\
\text { and other materials) } \\
\text { Participants (discussions } \\
\text { and written outputs in } \\
\text { flipcharts) } \\
\text { Cartoonist }\end{array}$ & $\begin{array}{l}\text { Report no } 1 \\
\text { Cartoons }\end{array}$ & $\begin{array}{l}\text { Sound facilitation, and } \\
\text { information elicitation } \\
\text { and gathering }\end{array}$ \\
\hline $\begin{array}{l}\text { Desk research } \\
\text { on GM and } \\
\text { engagement } \\
\text { issues }\end{array}$ & $\begin{array}{l}\text { The academic and } \\
\text { grey literatures }\end{array}$ & $\begin{array}{l}\text { Contractor } \\
\text { Subcontractor } 2\end{array}$ & Report no 2 & $\begin{array}{l}\text { Basic but fairly } \\
\text { comprehensive }\end{array}$ \\
\hline $\begin{array}{l}\text { Production of } \\
\text { stimulus } \\
\text { material }\end{array}$ & $\begin{array}{l}\text { Reports } 1 \text { and } 2 \\
\text { Debate Steering } \\
\text { Board members }\end{array}$ & $\begin{array}{l}\text { Contractor } \\
\text { Subcontractor } 3 \text { (analysis } \\
\text { of reports, and interviews } \\
\text { with, and comments from, } \\
\text { Board members) }\end{array}$ & $\begin{array}{l}\text { Video } \\
\text { Booklet } \\
\text { Text for website } \\
\text { Questionnaire }\end{array}$ & $\begin{array}{l}\text { Was the initial framing } \\
\text { captured adequately? } \\
\text { Decontextualized and } \\
\text { over-simplified } \\
\text { information in stimulus } \\
\text { materials }\end{array}$ \\
\hline $\begin{array}{l}\text { Public meetings } \\
\text { (Tier } 1 \text { ) }\end{array}$ & $\begin{array}{l}\text { Stimulus materials } \\
\text { Participants }\end{array}$ & $\begin{array}{l}\text { Participants } \\
\text { Subcontractors } 4 \\
\text { (facilitation) } \\
\text { Contractors (event } \\
\text { organization) }\end{array}$ & $\begin{array}{l}\text { Reports by } \\
\text { Steering Board } \\
\text { observers } \\
\text { Transcripts of } \\
\text { plenary } \\
\text { discussions } \\
\text { Questionnaire data }\end{array}$ & $\begin{array}{l}\text { Poor quality } \\
\text { mechanisms for } \\
\text { capturing discussion } \\
\text { Stimulus materials } \\
\text { largely ignored }\end{array}$ \\
\hline $\begin{array}{l}\text { Public meetings } \\
\text { (Tiers } 2 \text { and } 3 \text { ) }\end{array}$ & $\begin{array}{l}\text { Stimulus materials } \\
\text { Participants }\end{array}$ & $\begin{array}{l}\text { Participants } \\
\text { Subcontractors } 4 \\
\text { (facilitation for some Tier } \\
2 \text { events) } \\
\text { Contractors (event } \\
\text { organization for some Tier } \\
2 \text { events) } \\
\text { Local event organizers } \\
\text { (local government, } \\
\text { community groups, local } \\
\text { branches of pressure } \\
\text { groups etc.) }\end{array}$ & $\begin{array}{l}\text { Transcripts of } \\
\text { plenary } \\
\text { discussions for } \\
\text { those tier events } \\
\text { supported by } \\
\text { contractors } \\
\text { Reports provided } \\
\text { by organizers of } \\
\text { some Tier } 3 \\
\text { meetings } \\
\text { Questionnaire data }\end{array}$ & As above \\
\hline Website & Stimulus materials & Participants & $\begin{array}{l}\text { Comments left } \\
\text { behind (also some } \\
\text { e-mails and hard- } \\
\text { copy letters sent } \\
\text { by post) } \\
\text { Questionnaire data }\end{array}$ & $\begin{array}{l}\text { Not possible to comment } \\
\text { on participant } \\
\text { engagement with } \\
\text { website }\end{array}$ \\
\hline
\end{tabular}


Table 1. (continued)

\begin{tabular}{|c|c|c|c|c|}
\hline $\begin{array}{l}\text { Stage of } \\
\text { process }\end{array}$ & $\begin{array}{l}\text { Information/ } \\
\text { knowledge source }\end{array}$ & Actors/mechanisms & Outputs & Translation quality? \\
\hline \multirow{7}{*}{$\begin{array}{l}\text { Narrow-but- } \\
\text { Deep groups }\end{array}$} & Stimulus materials & Participants & Report no. 3 & Good quality facilitation \\
\hline & Cartoons from & \multirow{6}{*}{$\begin{array}{l}\text { Subcontractor } 1 \\
\text { (facilitation, and analysis } \\
\text { of audio recordings of } \\
\text { discussions and participant } \\
\text { diaries) }\end{array}$} & \multirow[t]{6}{*}{ Questionnaire data } & Implicit logic of method \\
\hline & Foundation & & & suspect? \\
\hline & Discussion & & & Diary process entailed \\
\hline & workshops & & & uncontrolled exposure \\
\hline & \multirow{2}{*}{$\begin{array}{l}\text { Information } \\
\text { accessed from } \\
\text { various sources by } \\
\text { participants during } \\
\text { two-week "diary" } \\
\text { period }\end{array}$} & & & $\begin{array}{l}\text { to a diversity of } \\
\text { information sources }\end{array}$ \\
\hline & & & & $\begin{array}{l}\text { Questionnaires } \\
\text { completed at the start of } \\
\text { second meetings of the } \\
\text { groups }\end{array}$ \\
\hline \multirow{4}{*}{$\begin{array}{l}\text { Final report } \\
\text { production }\end{array}$} & \multirow{4}{*}{$\begin{array}{l}\text { All data collected } \\
\text { by debate process }\end{array}$} & Subcontractor 5 (a & \multirow{4}{*}{$\begin{array}{l}\text { Report no. } 4 \text { (final } \\
\text { report on the } \\
\text { debate) }\end{array}$} & Severe time pressure \\
\hline & & professional writer) & & Methodologically \\
\hline & & $\begin{array}{l}\text { Contractors (some } \\
\text { analytical support for the } \\
\text { writer) }\end{array}$ & & $\begin{array}{l}\text { worrying analysis } \\
\text { of data }\end{array}$ \\
\hline & & $\begin{array}{l}\text { Debate Steering Board } \\
\text { (discussion of draft } \\
\text { materials) }\end{array}$ & & \\
\hline \multirow{4}{*}{$\begin{array}{l}\text { Interpretations } \\
\text { of final report }\end{array}$} & \multirow[t]{4}{*}{ Report no. 4} & Media & Media coverage & \multirow{4}{*}{$\begin{array}{l}\text { Worrying media } \\
\text { coverage based largely } \\
\text { of the questionnaire } \\
\text { data, suggesting that the } \\
\text { debate amounted to a } \\
\text { simple referendum }\end{array}$} \\
\hline & & Politicians & Posting of & \\
\hline & & Industry organizations & websites & \\
\hline & & Pressure groups & $\begin{array}{l}\text { Circulation of } \\
\text { documentation }\end{array}$ & \\
\hline
\end{tabular}

of GM issues (in the Foundation Discussion workshops) were steadily eroded throughout subsequent stages of the debate process. These framings were first transformed into stimulus materials that were rather bland, which failed to capture the contextual relevance of their sources, and were largely ignored by participants in the debate. It was not at all clear the extent to which these materials informed the deliberations that took place in the public meetings or Narrow-but-Deep groups, or their significance to those encountering the debate website. Attempts to capture the richness of such interactions were largely restricted to a small number of closed questions in the "feedback" questionnaire, which focused on ratings of a number of pre-assigned attributes of GM. Arguably these somewhat limited data were then over-interpreted by a small number of time-pressured individuals during the process of producing the debate's final report.

We summarize these findings in Table 1. Here we draw attention to how additional translation mechanisms, in particular provided by the media, politicians and pressure groups, rendered new understandings of what the debate had to say. It is important to note that media representations of the debate findings tended to portray the process as taking the form of a referendum, so indicating widespread public disapproval for GM crops and food. Such representations paid no attention to the atypical sampling that provided the basis for such a judgment. These processes, together with the translation of the debate outputs into policy (e.g. DEFRA et al., 2004), and the ongoing attempts to re-interpret the debate's findings (see e.g. letters to 
The Guardian newspaper, 24 July 2006) are all important matters for future research. Of course, these considerations concerning the debate's interaction with its operating environment - the influence of media coverage and political debate-applied throughout the course of the debate process. We discuss these matters in detail elsewhere (Horlick-Jones et al., 2007).

It would appear that in many ways there are similarities between the measures needed to establish quality control in social research and those that appear to be needed to achieve effective translation quality in the implementation of engagement processes. This recognition suggests a need to revisit notions of reliability and validity, the need for a clear audit trail through data collection and analysis (e.g. Seale, 1999), and a critical awareness of the inherent difficulties associated with combining distinct datasets through processes of triangulation (Fielding and Fielding, 1986). In view of the experimental and sometimes unpredictable nature of engagement initiatives, we also draw attention to the need for an enhanced attention to the social context in which data are generated, and to the logic of the position in which participants are placed (Houtkoop-Steenstra, 2000).

To conclude, we suggest that it is difficult to conceive of any type of citizen engagement exercise in which the effectiveness of information collection and transmission, and knowledge capture, will not be a relevant criterion of success. We therefore propose that translation quality should join the list of existing normative evaluation criteria that have begun to emerge from the literature on the evaluation of engagement processes.

\section{Acknowledgements}

The work reported in this paper was made possible by the generous financial support of the Leverhulme Trust (RSK990021), and by two awards from the Economic and Social Research Council (ESRC), including one from the Science in Society Programme (L144250037). Additional support (for THJ) was provided by the ESRC SCARR Programme (RES-336-250001). We thank the members of the GM Nation? Public Debate Steering Board, the debate secretariat, and staff at COI Communications and Corr Wilbourn Research and Development, for their cooperation and patience. We are pleased to acknowledge many helpful conversations with colleagues and fellow researchers, in particular with Graham Murdock, Tim O'Riordan, Judith Petts, Nick Pidgeon and Wouter Poortinga. We are also grateful to Tee Rogers-Hayden, who kindly provided us with access to unpublished research. We gratefully acknowledge the permission provided by Blackwell Publishing to reproduce Figure 1. Finally, we thank the three referees for their insightful comments and constructive suggestions.

\section{Notes}

1 Here we allude to the need for engagement exercises to fully take into account the material character, economics and other specific features of a given technology (see Button, 1993; Horlick-Jones and Sime, 2004).

2 Here we draw upon a limited analysis of the diaries conducted by Corr Wilbourn (2003b), and a detailed (but as yet unpublished) content analysis by Tee Rogers-Hayden.

\section{References}

Abelson, J., Forest, P.-G., Eyles, J., Smith, P., Martin, E. and Gauvin, F.-P. (2003) "Deliberations about Deliberative Methods: Issues in the Design and Evaluation of Public Participation Processes," Social Science and Medicine 57: 239-51.

Alvesson, M. (2004) Knowledge Work and Knowledge-Intensive Firms. Oxford: Oxford University Press.

Bloor, M., Frankland, J., Thomas, M. and Robson, K. (2001) Focus Groups in Social Research. London: SAGE.

Button, G. (1993) “The Curious Case of the Disappearing Technology," in G. Button (ed.) Technology in Working Order: Studies of Work, Interaction and Technology, pp. 10-28. London: Routledge. 
Campbell, S. and Townsend, E. (2003) "Flaws Undermine Results of UK Biotech Debate," Nature 425: 559.

CEC (2001) European Governance: a White Paper. Brussels: Commission of the European Communities.

Checkland, P. and Scholes, J. (1990) Soft Systems Methodology in Action. Chichester: Wiley.

Collins, H. and Evans, R. (2002) "The Third Wave of Science Studies: Studies of Expertise and Experience," Social Studies of Science 32(2): 235-96.

Corr Wilbourn (2003a) A Report on the Foundation Discussion Workshops Conducted to Inform the GM Public Debate. London: Corr Wilbourn Research and Development.

Corr Wilbourn (2003b) Qualitative Research on a Series of Reconvened Group Discussions for the 'Narrow but Deep' Strand of the GM Public Debate. London: Corr Wilbourn Research and Development.

DEFRA et al. (2004) The GM Dialogue: Government Response. London, Edinburgh, Cardiff and Belfast: Department of Environment, Food and Rural Affairs, Scottish Executive Government, Welsh Assembly Government, and Department of the Environment in Northern Ireland.

Dryzek, J. (2000) Deliberative Democracy and Beyond. Oxford: Oxford University Press.

Feldman, M. (1989) Order without Design: Information Processing and Policy Making. Stanford, CA: Stanford University Press.

Fielding, N. and Fielding, J. (1986) Linking Data. Newbury Park, CA: SAGE.

Funtowicz, S. and Ravetz, J. (1992) "Risk Management as a Post-normal Science," Risk Analysis 12: 95-7.

Goffman, E. (1975) Frame Analysis: an Essay on the Organization of Experience. Harmondsworth: Penguin.

Grove-White, R., Macnaghten, P., Mayer, S. and Wynne, B. (1997) Uncertain World: Genetically Modified Organisms, Food and Public Attitudes in Britain. Lancaster: Centre for the Study of Environmental Change.

Harper, R. (1998) Inside the IMF: an Ethnography of Documents, Technology and Organisational Action. San Diego, CA: Academic Press.

Horlick-Jones, T. (1998) "Meaning and Contextualisation in Risk Assessment," Reliability Engineering and System Safety 59: 79-89.

Horlick-Jones, T. (2005) "Informal Logics of Risk: Contingency and Modes of Practical Reasoning," Journal of Risk Research 8(3): 253-72.

Horlick-Jones, T. and Sime, J. (2004) "Living on the Border: Knowledge, Risk and Transdisciplinarity," Futures 36 : 441-56.

Horlick-Jones, T., Rowe, G., Walls, J., O'Riordan, T. and Pidgeon, N. (2002) "Proposals for the Evaluation of the UK Public Debate on the Possible Commercialisation of Genetically Modified Crops," memorandum considered by the GM Nation? Public Debate Steering Board, September.

Horlick-Jones, T., Walls, J., Rowe, G., Pidgeon, N., Poortinga, W., O’Riordan, T., Murdock, G., Tait, J. and Bruce, A. (2003) "Memorandum Submitted by the Understanding Risk Team and Collaborators," in House of Commons Environment, Food and Rural Affairs Committee, Conduct of the GM Public Debate, Eighteenth Report of the Session 2002-03, HC 1220, Ev50-Ev56. London: The Stationery Office.

Horlick-Jones, T., Walls, J., Rowe, G., Pidgeon, N., Poortinga, W., O'Riordan, T., Murdock, G., Tait, J. and Bruce, A. (2004) A Deliberative Future? An Independent Evaluation of the GM Nation? Public Debate about the Possible Commercialisation of Transgenic Crops in Britain, 2003. Understanding Risk Programme, Working Paper 0402. Norwich: School of Environmental Sciences, University of East Anglia.

Horlick-Jones, T., Walls, J., Rowe, G., Pidgeon, N., Poortinga, W. and O'Riordan, T. (2006) “On Evaluating the GM Nation? Public Debate about the Commercialisation of Transgenic Crops in Britain," New Genetics and Society, 25(3) pp. 265-288.

Horlick-Jones, T., Walls, J., Rowe, G., Pidgeon, N., Poortinga, W., Murdock, G. and O'Riordan, T. (2007) The GM Debate: Risk, Politics and Public Engagement. London: Routledge.

Horlick-Jones, T., Walls, J. and Kitzinger, J. (in press) "Bricolage in Action: Learning about, Making Sense of, and Discussing Issues about Transgenic Crops and Food," Health, Risk and Society.

Houtkoop-Steenstra, H. (2000) Interaction and the Standardized Survey Interview: the Living Questionnaire. Cambridge: Cambridge University Press.

Irwin, A. and Wynne, B., eds (1996) Misunderstanding Science: the Public Reconstruction of Science and Technology. Cambridge: Cambridge University Press.

Jensen, P.E. (2005) "A Contextual Theory of Learning and the Learning Organization," Knowledge and Process Management 12(1): 53-64.

Kuhn, T. (1970) The Structure of Scientific Revolutions, 2nd edn. Chicago: Chicago University Press.

Linell, P. (1998) "Discourse across Boundaries: On Recontextualizations and the Blending of Voices in Professional Discourse," Text 18(2): 143-57.

Manning, P. (1988) Symbolic Communication: Signifying Calls and the Police Response. Cambridge, MA: MIT Press. Marris, C., Wynne, B., Simmons, P. and Weldon, S. (2001) Public Perceptions of Agricultural Biotechnology in Europe (PABE), Final Report to the European Commission, FAIR CT98-3844, DG12-SSMI. Brussels: The European Commission. 
National Research Council (1996) Understanding Risk: Informing Decisions in a Democratic Society, ed. P. Stern and H. Fineberg. Washington DC: National Academy Press.

OECD (2001) Engaging Citizens in Policy-Making: Information, Consultation and Public Participation. PUMA Policy Briefing No.10. Paris: Organisation of Economic Co-Operation and Development.

Petts, J. (1997) “The Public-Expert Interface in Local Waste Management Decisions: Expertise, Credibility and Process," Public Understanding of Science 6: 359-81.

Petts, J., Horlick-Jones, T. and Murdock, G. (2001) Social Amplification of Risk: the Media and the Public. Sudbury: HSE Books.

Pidgeon, N., Poortinga, W., Rowe, G., Horlick-Jones, T., Walls, J. and O’Riordan, T. (2005) “Using Surveys in Public Participation Processes for Risk Decision Making: the Case of the 2003 British GM Nation? Public Debate," Risk Analysis 25(2): 467-79.

Prior, L. (2003) "Belief, Knowledge and Expertise: the Emergence of the Lay Expert in Medical Sociology," Sociology of Health and Illness 25: 41-57.

Public Debate Steering Board (2003a) GM Nation? The Findings of the Public Debate. London: Department of Trade and Industry. URL: http://www.gmnation.org.uk

Public Debate Steering Board (2003b) GM Nation? The Public Debate (the Debating Zone workbook). London: Department of Trade and Industry.

Rosenhead, J. and Mingers, J., eds (2001) Rational Analysis for a Problematic World Revisited: Problem Structuring Methods for Complexity, Uncertainty and Conflict. Chichester: Wiley.

Rowe, G. and Frewer, L. (2000) "Public Participation Methods: a Framework for Evaluation,” Science, Technology and Human Values 25(1): 3-29.

Rowe, G. and Frewer, L. (2004) "Evaluating Public-participation Exercises: a Research Agenda," Science, Technology and Human Values 29(4): 512-56.

Rowe, G., Horlick-Jones, T., Walls, J. and Pidgeon, N. (2005) "Difficulties in Evaluating Public Engagement Initiatives: Reflections on an Evaluation of the UK GM Nation? Public Debate about Transgenic Crops," Public Understanding of Science 14: 331-52.

Rowe, G., Horlick-Jones, T., Walls, J., Poortinga, W. and Pidgeon, N. (in press) "Analysis of a Normative Framework for Evaluating Public Engagement Exercises: Reliability, Validity and Limitations," Public Understanding of Science.

Rowe, G., Poortinga, W. and Pidgeon, N. (2006) "A Comparison of Responses to Internet and Postal Surveys in a Public Engagement Context," Science Communication 27(3): 352-75.

Schön, D. and Rein, M. (1994) Frame Reflection: Toward the Resolution of Intractable Policy Controversies. New York: Basic Books.

Seale, C. (1999) The Quality of Qualitative Research. London: SAGE.

Stirling, A. and Meyer, S. (1999) Rethinking Risk. Brighton: Science and Technology Policy Research Unit.

Walls, J., Horlick-Jones, T., Niewöhner, J. and O’Riordan, T. (2005) "The Meta-governance of Risk: GM Crops and Mobile Telephones," Journal of Risk Research 8(7-8): 635-61.

Williams, G. and Popay, J. (1994) "Lay Knowledge and the Privilege of Experience," in J. Gabe, D. Kelleher and G. Williams (eds) Challenging Medicine, pp. 118-39. London: Routledge.

Wynne, B. (1995) "Public Understanding of Science," in S. Jasanoff, G. Markle, J. Petersen and T. Pinch (eds) Handbook of Science and Technology Studies, pp. 361-88. Thousand Oaks, CA: SAGE.

\section{Authors}

Tom Horlick-Jones is an independent researcher and consultant, currently based at the School of Social Sciences at Cardiff University. He was team leader of the GM Nation? public debate evaluation project. Over a period of some twenty years he has specialized in issues concerned with applied and conceptual aspects of risk, organizations and decision-making. His research is much concerned with the roles of talk, practical reasoning and knowledge in these areas. His publications include Natural Risk and Civil Protection (co-editor; Spon, 1995), Social Amplification of Risk: the Media and the Public (co-author; HSE Books, 2001) and The GM Debate: Risk, Politics and Public Engagement (with Gene Rowe, John Walls et al.; Routledge, 2007). Correspondence: Cardiff School of Social Sciences, Cardiff University, Glamorgan Building, King Edward VII Avenue, Cardiff CF10 3WT, Wales, UK; e-mail: Horlick-JonesT@Cardiff.ac.uk 
Gene Rowe is Head of Consumer Science at the Institute of Food Research, Norwich (UK). His Ph.D., gained from the Bristol Business School at the University of the West of England, concerned the use of nominal groups to improve human judgment and decision-making. As well as a continuing interest in judgment and decision-making, his research activities and publications have also spanned topics from expert systems and forecasting to risk perception and public participation. Much of his recent work has focused on the issue of evaluating the effectiveness of public participation exercises.

John Walls is a Senior Research Associate in the School of Environmental Sciences at the University of East Anglia. He has conducted research in a number of areas including: the governance of risk and new technologies; safety culture and industrial risk management; practical reasoning by lay publics about GM crops and food; public trust in government agencies; and the contribution of social science research to risk assessment. He is currently working on stakeholder involvement in decision-making about long-term radioactive waste management, as part of an international comparative study. 